\title{
KONSEP PEMIKIRAN PENDIDIKAN ISLAM KH. HASYIM ASY'ARI DAN SYAIKH AHMAD KHATIB AL-SAMBASI
}

\section{Rahamad Ari Wibowo}

Institut Agama Islam Negeri (IAIN) Metro

Jl. Ki. Hajar Dewantara 15 A Kampus Iring Mulyo, Metro Timur

Kota Metro 34111

Email: rahmadariwibowo132@gmail.com

\begin{tabular}{|c|c|c|}
\hline Diterima: & Revisi: & Disetujui: \\
10 Maret 2018 & 10 April 2018 & 22 Mei 2018 \\
\hline
\end{tabular}

\begin{abstract}
This paper reviews the concept of Islamic education thinking Hasyim Ash'ari which explains about how the rules of teaching and learning that emphasizes the ethical aspects of learning. The concept of Islamic education Hasyim Ash'ari is one of the bids in overcoming the spiritual crisis in the world of education today. Hasyim Asy'ari's educational thought does have high spiritual values of Sufism. This is due, Hasyim Asy'ari put tasawuf as the foundation of education in shaping the character of learners who berakhlatul karimah and intlektual. The concept of Islamic education Hayim Ash'ari, if associated with the Concept of Sufism Ahmad Khatib Al-Sambasi not only complement each other but strengthen the theory of Islamic education Hasyim Asy'ari. Hashim Asy'ari's education theory is very relevant in shaping the character of learners in their morals, intellectual and spirituality in this modern era. Modern education today, tends to emphasize the cognitive aspect although in educational theory there are elements of cognitive, affective and psychomotor aspects. This is what resulted in the lack of "blessing" knowledge of learners in gaining knowledge. One of the most important parts to be considered and emphasized in addition to the cognitive aspect is the affective aspect (spirituality and ethics) in the teaching and learning process, whether as a teacher or pupil in education. It is time for education to focus on affective aspects (moral, ethical and spiritual). Spiritual, ethical and moral crises are an important study in the world of education, especially Islamic-based education.
\end{abstract}

Key Word : Educational Thought, Concept of Sufism, Spiritual Crisis and Ethical Crisis. 


\begin{abstract}
Abstrak
Tulisan ini mengulas tentang konsep pemikiran pendidikan Islam Hasyim Asy'ari yang menjelaskan tentang bagaimana kaidah-kaidah dalam belajar mengajar yang menekankan pada aspek etika belajar. Konsep pendidikan Islam Hasyim Asy'ari merupakan salah satu tawaran dalam mengatasi krisis spritual di dunia pendidikan saat ini. Pemikiran pendidikan Hasyim Asy'ari memang mempunyai nilai-nilai spritualitas tasawuf yang tinggi. Hal ini disebabkan, Hasyim Asy'ari meletakkan tasawuf sebagai pondasi pendidikan dalam membentukkan karakter peserta didik yang berakhlatul karimah dan intlektual. Konsep pendidikan Islam Hayim Asy'ari, jika dikaitkan dengan Konsep tasawuf Ahmad Khatib Al-Sambasi bukan hanya sekedar saling menlengkapi satu sama lain, melainkan memperkuat teori pendidikan Islam Hasyim Asy'ari. Teori pendidikan Hasyim Asy'ari sangat relevan dalam membentuk karakter peserta didik berakhlakul karimah, intlektual dan spritualitas di era modern ini. Pendidikan modern saat ini, cenderung menekankan pada aspek kognitif meskipun dalam teori pendidikan terdapat unsur aspek kognitif, afektif dan pskomotorik. Hal ini lah yang mengakibatkan kurangnya "keberkahan" ilmu dari peserta didik dalam menimba ilmu pengetahuan. Salah satu bagian terpenting yang harus diperhatikan dan ditekankan selain pada aspek kognitif adalah aspek afektif (spritualitas dan etika) dalam proses belajar mengajar, baik sebagai guru atau murid dalam pendidikan. Sudah saatnya pendidikan lebih mengutamakan aspek afektif (moral, etika dan spritual). Krisis spiritual, etika dan moral menjadi kajian penting dalam dunia pendidikan terlebih pendidika berbasis Islam.
\end{abstract}

Kata Kunci : :Pemikiran pendidikan, Konsep Tasawuf, Krisis Spritual dan Krisis etika

\title{
A. Pendahuluan
}

Spritualitas menjadi salah satu bagian yang penting dalam dunia pendidikan di era modernisasi saat ini. Maksud spiritualitas dalam hal ini adalah kesucian jiwa dan ketakdziman seorang murid pada gurunya. Seiring dengan perkembangan zaman, pendidikan telah mengalami pergeseran orientasi dan krisis spiritual. Pendidikan yang berorientasi pada mencerdaskan bangsa telah bergeser pada kapitalisme pendidikan. Begitupula dengan nilai-nilai spritual dalam pendidikan semakin terkikis oleh nalar modernisasi yang telah masuk dalam dunia pendidikan sehingga tidak mengendahkan etika-etika dalam belajar. 
Etika dalam belajar dan mengajar sangat mempengaruhi dalam menanamkan nilai-nilai spritual dalam pendidikan; seperti menghormati guru, ta'dzim kapada guru dan orang tua, berpakaian yang rapi, berbicara dengan baik, berdoa sebelum dimulainya pelajaran dan taat beribadah kepada Allah SWT. Nilai-nilai spritual harus lebih ditekankan dalam pendidikan untuk membentuk mental dan pikiran peserta didik yang intlektual dan bertakwa kepada Tuhan Yang Maha Esa.

Selanjutnya, ke-takdziman seorang murid kepada guru merupakan salah satu nilai spritual dalam pendidikan yang sangat mempengaruhi keberhasilan peserta didik dalam menuntut ilmu pengetahuan. Tanpa ke-takdziman seorang murid kepada gurunya, maka ilmu pengetahuan yang dipelajari akan tidak membawa manfaat dalam hidup. Konsep ke-takdziman seorang murid pada guru merupakan sistem pendidikan yang sangat ditekan pada masa dahulu. Sistem pendidikan yang masih mengutamakan ke-takdziman seorang murid kepada gurunya, hingga saat ini adalah sistem pendidikan pondok pesantren, yang sistem pendidikan dalam kegiatan belajar mengajarnya merujuk pada kitab taklim muatalim.

Pendidikan yang tidak memperhatikan ke-takdziman dalam kegiatan belajar mengajar, kemungkinan besar akan terjadi tindak kekerasan murid kepada gurunya dan Ketidak manfaatan ilmu pengetahuan dalam hidup. Sebuah tindak kekerasan yang dilakukan oleh murid kepada guru Seperti melawan, menantang atau memukul, merupakan salah bentuk tidak adanya rasa takdzim seorang murid kepada gurunya terlebih pendidika di era modernisasi ini.

Konsep Pendidikan Hasyim Asy'ari dan Ahmad Khatib al-Sambasi merupakan sebuah bentuk tawaran dalam mengatasi krisis spiritual dalam dunia Pendidikan. Bagaimana pola pendidikan saat ini perlu melakukan evaluasi kembali berkaitan dengan mentalitas dan spiritual peserta didik. Banyak fakta-fakta dalam Pendidikan yang tidak memperhatikan kesucian jiwa dan ketadziman mengakibatkan tindak kriminal murid kepada gurunya bahkan sampai ke jalur hukum. 


\section{B. Biografi KH. Hasyim Asy'ari dan Syaikh Ahmad Khatib al- Sambasi}

\section{KH. Hasyim Asy'ari}

Hasyim Asy'ri dilahirkan di desa Nggedang salah satu desa yang terletak di Kabupaten Jombang-Jawa Timur bertepetan pada hari Selasa Kliwon, tanggal 24 Dzulqai'idah 1287 H. Adapun nama lengkap Hasyim adalah Muhammad Hasyim Asy'ary ibn abd alWahid ibn al-Halim yang mempunyai sebuah gelar pangeran Bona ibn Abd al- Rahman yang termashur dengan sebutan Jaka Tingkir Sultan Hadiwijaya ibn Abdallah ibn Abd al-Aziz ibn Abd al-Fatah ibn Maulana Ishal dari Raden Ain al-Yaqin yang termashur dengan sebutan Sunan Giri. ${ }^{1}$

Hasyim Asy'ari ini dibesarkan dalam keluarga agamis dan hidup dalam dunia pesantren. Di lingkungan pesantren Hasyim Asy'ari menempuh ilmu pengetahuan agama dan mendapatkan pendidikan tentang ke-Islaman. Diusianya yang kelima tahun, Hasyim kecil mendapatkan pendidikan langsung dari asuhan orang tua dan kakeknya di Pondok Pesantren Gedang. Awal permulaan, Hasyim belajar kepada ayahnya sendiri kemudian Hasyim bergabung dan berproses bersama santri-santri lain di pondok pesantren untuk memperdalam ilmu agama Islam. Di pondok pesantren inilah, Hasyim berproses menggeluti ilmu pengetahuan dan minat baca sangatlah tinggi sehingga membentuk karakter, kepribadian dan pemikiran Hasyim. Hasyim banyak membaca literatur-literatur agama dan umum. ${ }^{2}$ Lingkungan Pondok Pesantren sangat mempengaruhi kepribadian Hasym Asy'ari. Hasym selain gemar membaca, beliau juga mempunyai kecerdasan intlektual yang tinggi.

Hasyim diusia muda, memulai melakukan pengembaraan ke berbagai pondok pesantren di luar kota Jombang untuk memperdalam ilmu pengetahuan agama. Adapun beberapa

\footnotetext{
1 Ramayulis dan Samsul Nizar, Ensiklopedi Tokoh Pendidikan Islam, (Ciputat: PT. Ciputat Press Group, 2005), h. 214

2 Ibid, h. 215.
} 
pondok pesantren yang sempat menjadi tempat Hasyim menempuh dan mempelajari ilmu pengetahuan agama adalah Pondok Pesantren Wonokojo di Purbolinggo, Pesantren Langitan di Tuban, Pesantren Trenggilis, Pesantren Kademangan Bangkalan Madura, Pesantren Siwalan Panji, Sidoarjo. Selama di Pondok Pesantren Siwalan Panji di bawah naungan Kiai Ya'qup, akhirnya Hasyim menikah dengan putri pengasuh Pesantren Siwalan, Kiai Ya'qub yang bernama Khadijah pada tahun $1892 .^{3}$

Usia pernikahan yang belum begitu lama, Hasyim beserta istri dan mertua menunaikan rukun Islam yang kelima, yakni menunaikan ibadah Haji ke Baitullah al-Mukaromah Kota Mekkah dan selanjutnya Hasyim menimba dan memperdalam ilmu pengetahuan agama. Hasyim menimba ilmu agama di Kota Mekkah tidaklah lama, sejak istrinya meninggal dunia karena melahirkan, Hasyim kembali pulang ke tanah air Indonesia.

Tingkat ghirah yang kuat, rasa haus terhadap ilmu pengetahuan agama yang dalam menjadikan Hasyim kembali ke tanah suci Mekkah, dengan ditemani saudaranya yang bernama Anis. Hasyim bermukim di kota suci Mekkah kurang lebih selama tujuh tahun dan berguru kepada ulama-ulama besar seperti Syaikh Sayyid Sultan ibn Hasyim, Ahmad Amin al-Aththar, Syaikh Shaleh Bafadhal, Sayyid Abdullah al-Zawawi, dan Syaikh Sultan Hasyim Dagastani. 4

Pada tahun 1900 Hasyim kembali ke tanah air Indonesia dan menjadi seroang ustadz mengajarkan ilmu agama di pondok pesantren milik ayahnya dan kakeknya. Setelah sekian lama Hasyim menduda, akhirnya Hasyim menikah dengan seorang putri yang bernama Nafiah, putri Kiai Ramli Pengasuh Pondok Pesantren Kuningan, Kediri. Tidak lama diusia pernikahannya Hasyim mendirikan Pondok Pesantren Tebu Ireng yang terletak di Kota Jombang pada tanggal 6 Februari 1906. Pondok Pesantren

3 Ibid.

4 Zainal Abidin, Filsafat Pendidikan Islam, (Metro: STAIN Jurai Siwo Metro Lampung, 2013) h. 176. 
Tebu Ireng merupakan tempat tempahan para kader ulama-ulama Jawa dan terkenal diseluruh penjuru Nusantara. ${ }^{5}$ Selanjutnya, mengajar dan mendidik merupakan hal yang sangat ditekuni oleh Hasyim. Beliau mengajar sejak pertama kali mondok di pesantren. Tidak hanya itu, beliau juga sempat mengajarkan ilmu agama di Kota Makkah. Sepulangnya beliau sampai di tanah air Indonesia menghabiskan waktu untuk agama dan ilmu serta mengajar para santri di pondok pesantren yang beliau dirikan. ${ }^{6}$

Hasyim Asy'ari meninggal pada tanggal 7 Ramadhan 1366 H/ 25 Juli 1974 M di Tebu Ireng Jombang. Beliau meninggal dunia di usianya yang ke 79 tahun. Hasyim meninggal dunia dikarenakan sakit darah tinggi. Tekanan darah tinggi Hasyim kambuh dikarenakan, beliau mendapat informasi dari seorang pejuang bangsa Bung Tomo dan Jenderal Sudirman bahwa pasukan belanda telah masuk ke Indonesia di bawah pimpinan Jenderal Sporr. Informasi ini membuat Hasyim sangat terkejut dan mendadak stroke, sakit stroke yang diderita beliau mengakibatkan kematiannya.

Hasyim Asy'ari salah satu ulama besar di Indonesia yang berjuang menegakkan dan mengajarkan agama Islam serta menjaga keutuhan bangsa Indonesia. Meninggalnya beliau karena mendapatkan berita dari Jendral Sudirman yang mengakibatkan sakit dan kematian beliau, merupakan bukti bahwa Hasyim bukan hanya sekedar pejuang agama Islam melainkan bagian dari para pejuang yang menjaga keutuhan bangsa Indonesia dan NKRI. Kemerdekaan Indonesia tidak bisa dilepaskan dari peran para tokoh pemuka agama Islam. Banyaknya pemuka agama di Indonesia memperngaruhi kestabilitas negara Indonesia itu sendiri.

${ }^{5}$ Samsul Nizar, Filsafat Pendidikan Islam Pendekatan Historis Teoritis dan Praktis, (Jakarta Selatan: Ciputat Pers, 2002), h. 153.

${ }^{6}$ Ibid. 


\section{Syaikh Ahmad Khatib al-Sambasi}

Ahmad Khatib Sambas mempunyai nama lengkap Ahmad Khatib Al-Sambasi adalah Syaikh Muhammad Khatib ibn 'Abd. AlGhaffar al-Sambasi al-Jawi. Beliau berasal dari kampung Dagang (sumber lain terdapat penjelasan bahwa beliau berasal dari kampung Asam, Sambas), dan meninggal pada tahun 1878.7 Sementara itu, dalam litertaur lain dijelaskan bahwa beliau lahir pada tahun 1803 M, di Sambas, Kalimantan Barat. Ayahnya bernama Abdul Ghaffar bin Abdullah bin Muhammad bin Jalaluddin. Ahmad Khatib merupakan keluarga perantau dari desa Kampung Sange. ${ }^{8}$

Ahmad Khatib sejak kecil memiliki keistimewaan sendiri, bila dibandingkan dengan teman-teman sebayanya. Ahmad Khatib merupakan salah satu ulama besar dari Indonesia yang tinggal di kota Makkah sampai di akhir hayatnya. Riwayat Pendidikan beliau banyak dihabiskan di kota Makkah. Selama Ahmad Khatib berdomisili di kota Makkah banyak pelajar Indonesia yang belajar mukim di kota Makkah belajar ilmu agama kepada Ahmad Khatib. Ilmu agama Ahmad Khatib sangatlah dalam dan beliau mendirikan jamaah dzikir tarekat Qadiriah Naqsyabandiah.

Ahmad Khatib ahli dibidang tarekat, bahkan beliau lebih diakui dibidang tarekat, sedangkan di bidang ilmu yang lain kurang diketahui. Ahmad Khatib sebagaimana dinyatakan oleh Syaikh Ahmad ibn Muhammad Syaikh ibn Mustofa al-Fatani dalam buku melacak pemikiran tasawuf dinyatakan, bahwa Ahmad Katib selain lebih dikenal dan diakui dibidang tarekat, beliau juga sangat mengusai ilmu fiqih, hadis, dan hafal al-Quran. ${ }^{9}$

Ahmad Khatib mempunyai karomah dari Allah SWT. Sebagaimana dikisahkan, bahwa di tepi rumah Ahmad Khatib

7 Solihin, Melacak Pemikiran Tasawuf di Nusantara, (Jakarta: PT. Raja Grafindo, 2005), h. 314

8 Dikutip dari wekipedia https://id.wikipedia.org/wiki/Achmad_Khotib_alSyambasi, pada tanggal 19 Februari 2018. Pukul 09.00 WIB.

${ }^{9}$ Ibid. 
terdapat pohon asam jawa. Pohon asam ini selalu mengikuti dan melindungi Ahmad Khatib ke mana dan di manaun beliau berada. Suatu saat, Ahmad Khatib pergi mandi ke sungai Sambas, pohon asam jawa pun mengikutinya di sebelah kanannya dan pulangnya pohon asam berada di sebalah kirinya. ${ }^{10}$

Karomah yang dimiliki oleh Ahmad khatib merupakan hal yang wajar karena beliau adalah pendiri tarekat Qadiriah Naqsabandiah. Beliau belajar pada gurunya Syeikh Syams al-Din, Ahmad Khatib dilantik menjadi Syeikh Mursid Kamil al-Mukamil dalam lingkungan ajaran Syeikh Syam al-Din, setelah beliau Syeikh Syam al-Din meninggal dunia. ${ }^{11}$ Ahmad Khatib dalam meneruskan perjuangan gurunya dengan status sebagai Mursid tarekat Qodariah Naqsyabandiah.

Syaikh Ahmad Khatib al-Sambasi mempunyai peran besar dalam menyebarkan paham tarekat Naqsabandiah Mazhariah dan Qodiriah Naqsabandiah di Indonesia. Tarekat Qodiriah Naqsabandiah adalah gabungan dari tarekat Qodiriah dan Naqsabandiah yang kemudian oleh Ahmad Khatib digabung dalam satu tarekat bernama tarekat Qadiriah Naqsabandiah. Ahmad Khatib memiliki jamaah tarekat Qadiriah Naqsabandiah di daerah jawa kurang lebih berjumlah tiga juta orang. ${ }^{12}$ Sebagai seorang mursyid, Syeikh Ahmad Khatib Sambasi, mempunyai kekuasan penuh dalam memodifikasi tarekat yang beliau pimpin.

\section{Pokok-pokok Pikiran KH. Hasyim Asy'ari dan Syaikh Ahmad Khatib al-Sambasi}

1. Kitab Adab al-Alim wa Muta'alim: Pokok Pikiran Pendidikan dan Etika Belajar KH. Hasyim Asy'ari

Salah satu karya KH. Hasyim Asy'ari yang termashur dalam konteks Pendidikan adalah kitab Adab al-Alim wa Muta'alim fima Yahtaj Ilah al-muta'alim Maqamat Ta'limih yang dicetak pertama

\footnotetext{
10 Ibid., h. 315

11 Ibid., h. 317

12 Ibid., h. 320
} 
kali pada tahun $1415 \mathrm{H}$. Kitab ini menjelaskan tentang masalahmasalah pendidikan yang menekankan pada etika dalam kegiatan belajar mengajar. Etika merupakan bagian yang terpenting yang perlu diperhatikan dalam pendidikan. ${ }^{13}$

Selanjutnya, untuk memahami kitab al-Alim wa Muta'alim fima Yahtaj Ilah al-muta'alim Maqamat Ta'limih lebih mendalam maka terlebih dahulu perlu memahami latar belakang lahirnya kitab adab tersebut. Adapun latar belakang terbitnya kitab Adab al-Alim wa Muta'alim fima Yahtaj Ilah al-muta'alim Maqamat Ta'limih dilatarbelakangi oleh situasi dan kondisi pendidikan waktu itu yang mengalami perkembangan pesat terutama pergeseran paradigma dan budaya tradisional ke dalam bentuk dan budaya modern. ${ }^{14}$

Pemikiran pendidikan KH. Hasyim Asy'ari tertuang dalam kitabnya adab al-Alim wa Muta'alim fima Yahtaj Ilah al-muta'alim Maqamat Ta'limih. Kitab ini menjelaskan betapa pentingnya sebuah etika dalam kegiatan belajar mengajar. Beberapa karya KH. Hasyim Asy'ari yang lain mempunyai titik persamaan yaitu menekankan pada etika belajar dan tauhid. Etika memang merupakan bagian terpenting dalam pendidikan dan mendidik. Terdapat beberapa adab atau etika pada konteks kegiatan belajar mengajar.

Selanjutnya, dalam proses pendidikan, di dalam kegiatan belajar mengajar terdapat beberapa etika utama yang harus ditaati dan dilaksanakan oleh peserta didik (santri). Pertama, murid harus mempunyai niat yang tulus suci dalam menuntut ilmu pengetahuan dan tidak diperkenankan menuntut ilmu berniat duniawi. Kedua, sebagai pendidik, guru harus meluruskan niatnya dalam menyampaikan ilmu pengetahuannya. Niat mendidik karena Allah SWT dan tidak diperkenankan mengajar dan mendidik berorientasi materi duniawi serta sikap tindakan

13 Ramayulis dan Samsul Nizar, Ensiklopedi Tokoh Pendidikan Islam..., h. 218.

14 Ibid. 
guru harus sesuai dengan apa yang diajarkan. ${ }^{15}$ Pendidik memiliki peran dan pengaruh besar terhadap peserta didik. Ilmu pengetahuan yang dimiliki oleh pendidik ketika diajarkan akan membentuk karakter peserta didik.

Lebih detail pemikiran beliau tentang etika tertuang dalam kitab adab al-Alim wa Muta'alim fima Yahtaj Ilah al-muta'alim Maqamat Ta'limih, yang didalam kitab tersebut teradapat delapan bab, yaitu: keutamaan ilmu dan ilmuan serta keutamaan belajar mengajar; etika yang harus diperhatikan dalam belajar mengajar; etika seorang murid kepada guru; etika murid terhadap pelajaran dan hal-hal yang harus di pedomi bersama guru; etiak seorang guru; etika guru dalam mengajar; etiak guru kepada muridmuridnya; dan etika kepada buku. Dari delapan bab tersebut dapat di kelompokkan dalam tiga kelompok, yaitu signifikansi pendidikan, tugas dan tanggung jawab seorang murid, dan tugas tanggung jawab seorang guru. ${ }^{16}$

Lebih mendalam lagi, pemikiran KH. Hasyim Asy'ari tentang pendidikan Islam mempunyai ciri khas sendiri, yaitu lebih mengedepankan etika dalam proses kegiatan belajar mengajar. Sejalan dengan peryataan Zainal Abidin dalam karyanya "Filsafat Pendidikan Islam," menyatakan bahwa, metodologi pemikiran KH. Hasyim Asyari dapat dipetakan dalam dua pemikiran. Pertama, pemikiran tradisional yang lebih mengutamakan adab dalam proses pendidikan Islam terlebih pendidikan di pondok pesantren dalam mewari pemikiran-pemikiran Islam klasik, pemikiran Islam yang dipengaruhi oleh tasawuf Imam Al-Ghazali. Kedua, dalam proses kegiatan belajar mengajar, murid harus memperhatikan etika kepada gurunya. ${ }^{17}$

Beberapa etika murid terhadap gurunya yang harus diperhatikan setidaknya terdapat dua belas etika yaitu mendengar dan memperhatikan penjelasan guru, berhati-hati dalam memilih

\footnotetext{
15 Zainal Abidin, Filsafat Pendidikan Islam..., h. 178.

16 Ramayulis dan Samsul Nizar, Ensiklopedi Tokoh Pendidikan Islam..., h. 219.

17 Zainal Abidin, Filsafat Pendidikan Islam..., h. 179.
} 
guru, selain profesional, mengikuti jejak guru, memuliakan guru, memahami apa dan memperhatikan hak guru, bersabar terhadap hukuman dari guru, bersilaturrohmi di kediaman guru, duduk dengan santun dihadapan guru, berbicara dengan sopan dan lemah lembut di hadapan guru, mendengarkan semua nasihatnya, jangan sekaliu-kali menyela ketika guru menjelaskan, dan menggunakan anggota badan sebelah kanan ketika melakukan sesuati tindakan dihadapan guru dan orang lain. ${ }^{18}$ Adapun pemikiran-pemikiran KH. Hasyim Asy'ari secara detail dapat dibagi beberapa bagian; Pertama, etika Murid dalam belajar. Kedua, etika guru dalam mengajar. Ketiga, etika terhadap buku pelajaran. ${ }^{19}$

Berkaitan dengan pemikiran pendidikan Islam KH. Hasyim Asy'ari yang pertama yaitu etika murid dalam belajar mempunyai maksud bahwa dalam proses kegiatan belajar mengajar murid terlebih dahulu membersihkan hati dari hal-hal yang bersifat keduniaan dan meluruskan niat dalam belajar. Kedua, etika guru dalam mengajar bermaksud, bahwa dalam kegiatan belajar mengajar seorang guru haruslah senantiasa selalu mendekatkan diri kepada Allah SWT dan takut kepada-Nya serta guru sebelum memulai kegiatan belajar mengajar haruslah mensucikan diri dari kotoran, hadats dan najis. Ketiga, etika terhadap buku pelajaran maksudnya adalah dalam sebuah kegiatan belajar mengajar hendaknya seorang murid memperhatikan meminjamkan bukunya dengan ikhlas terhadap temannya jika temanya ingin meminjam bukunya.

Berdasarkan hal tersebut, maka berdasarkan pada pemikiran pendidikan KH. Hasyim Asy'ari di atas, jika kita pahami secara seksama sangatlah mengutamakan kesucian hati, kerendahan hati, mendekatkan diri kepada Allah SWT, dan sangat menekankan pada etika dalam proses kegiatan belajar mengajar. Hal ini

19 Ibid, h. 81. 
merupakan hal yang wajar jika KH. Hasyim Asy'ari mempunyai pemikiran pendidikan yang bercorak tasawuf karena pemikiran Hasyim sangat dipengaruhi oleh pemikiran Imam Al-Ghazali. ${ }^{20}$ Meskipun pemikiran pendidikan Islam Mbah Hasyim dipengaruhi oleh Imam Al-Ghazali, namun dalam konteks pendidikan terlebih di Indonesia sangatlah relevan untuk diterapkan dalam kegiatan belajar mengajar terutama dalam pendidikan pondok pesantren dan madrasah.

Baik dalam pemikiran maupun aplikasinya, mbah Hasyim cenderung menekankan pada akhlak atau etika karena dalam pendidikan Islam, etika merupakan pondasi yang paling utama. Ilmu tanpa akhlak yang mulya ibarat pohon yang rindang tak berbuah, begitu pula sabaliknya akhlak yang mulia haruslah diimbangi dengan ilmu pengetahuan yang luas agar anak didik mempunyai karakter berakhlak mulia dan mempunyai wawasan ilmu pengetahuan luas dengan sikap yang rendah hati dan selalu menjaga kesucian hati.

\section{Toriqoh Qodiriah Naqsabandiah: Pokok Pendidikan dan Etika} Belajar Syaikh Ahmad Khatib Al-Sambasi

Ahmad Khatib Al-Sambasi sebagai pendiri Toriqoh Qodiriah Naqsabandiah mempunyai beberapa ajaran yang bercorak tasawuf. Toriqoh Qodiriah Naqsabandiah ini mempunyai corak tasawuf yang berbeda dari aliran toriqoh lainnya. Adapun salah satu ciri khasnya adalah meninggalkan keduniaan, merupakan salah satu ajaran tasawuf Ahmad Khatib As-Sambasi. Hadirnya aliran-aliran toriqoh di Indonesia mempunyai peran besar dan memberikan sumbangsih perubahan masyarakat yang agamis dan sosialis.

Maraknya aliran-aliran toriqoh di Indonesia yang mempunyai ciri khas masing-masing disetiap aliran bukan hanya berdampak pada perubahan kehidupan masyarakat, tetapi selain mengubah

20 Ibid, h. 81. 
akidah pengikut salah satu aliran toriqoh, juga mengubah struktur pola fikir masyarakat terutama pengikut aliran toriqoh tersebut. Tasawuf memang merupakan salah satu jalan dalam mengatasi kebutuan persoalan duniawi. Dengan menekuni, mempelajari dan mengamalkan toriqoh dapat mensucikan hati, mensucikan fikiran dan menumbuhkan kesadaran tentang hakikat hidup adalah mendekatkan diri kepada-Nya serta mengharapkan ridhonya.

Kesucian hati, kesucian fikiran dan meninggalkan keduniaan dalam tasawuf merupakan syarat utama yang harus ditempuh bagi seseorang yang ingin memperdalam tasawuf terlebih dalam aliran-aliran toriqoh tertentu. Mensucikan hati, fikiran dan meninggalkan hal-hal yang bersifat keduniaan memerlukan latihan bathin secara kusus karena dalam tasawuf terdapat maqomat dan ahwal dalam mencapai ma'rufatullah.

Langkah awal dalam proses mensucikan hati, fikiran dan meninggkalkan hasrat duniawi yang harus dilakukan bagi seorang yang hendak menekuni ilmu toriqoh adalah pertama, niat, ikhlas, dan tulus. Kedua, Zuhud. Ketiga, Istiqomah. Keempat, sabar dan syukur. Kelima, tawakal. Keenam, ridha. ${ }^{21}$ Keenam poin tersebut merupakan kunci utama dalam proses pensucian hati dan awal dari kebahagiaan yang hakiki.

Adapun proses dalam mensucikan hati dan fikiran melalui beberapa tahapan yang dalam tasawuf disebut dengan maqomat (tahap-tahap) dan ahwal (keadaan mental). Adapun tahapan maqomat menurut al-Thusi; al-taubah, al-zuhud, al-wara, 'al-sabr, al-tawakkul, dan al-ridha. ${ }^{22}$ Dalam versi lain menjelaskan bahwa tingkat maqomat adalah tobat, zuhud, fakir, sabar, syukur, rela/rida, tawakal. ${ }^{23}$ Maqomat dan ahwal ini merupakan suatu hal keniscayaan yang harus dilalui bagi seseorang yang hendak menekuni dunia tasawuf maupun dunia toriqoh.

\footnotetext{
21 Yunasril Ali, Pilar-Pilar Tasawuf, (Jakarta: Kalam Mulia, 2005), h. 2.

22 Dahlan Tamrin, Tasawuf Irfani, (Malang: UIN Maliki Press, 2010), h. 31.

23 Rosihon Anwar, Akhlak Tasawuf, (Bandung: CV Pustaka Setia, 2010) h. 199202.
} 
Bunga-bunga dari maqomat dan ahwal akan membentuk kepribadian yang baik dan berfikiran baik serta bertindak sesuai dengan aturan agama Islam. Bangunan dari bersikap, berikir dan bertindak baik bukanlah seperti membalik telapak tangan melainkan melalui usaha bathin secara sungguh-sungguh. Baik dalam konteks tasawuf mempunyai arti sesuatu yang mempunyai nilai kebenaran atau nilai yang diharapkan dan memberikan kepuasan serta mendatangkan rahmat, memberikan perasaan senang dan bahagia. ${ }^{24}$

Kebahagian merupakan bagian dari perbuatan baik karena salah satu letak kebahagiaan adalah mensyukuri nikmat Allah SWT. Meskipun hidup dalam keterbatasan fisik dan ekonomi jika kita mensyukuri apa yang sudah merupakan anugrah pemberian Allah SWT maka kita akan sangat merasa bahagia. Kebahagian yang terletak pada mensyukuri nikmat Allah SWT merupakan salah satu bentuk keimanan kepada-Nya. Dalam penjelasan lain buah dari syukur nikmat Allah SWT ialah seseroang salah satunya berkepribadian santun kepada Allah dan semua ciptaan-Nya.

Berkepribadian baik atau beretika baik merupakan salah satu ajaran toriqoh Qodiriah Naqsabandiah, Ahmad Khatib Al-Sambasi. Adapun pemikiran atau ajaran tasawuf toriqoh Qodiriah Naqsabandiah, Ahmad Khatib Al-Sambasi terdapat empat pokok utama yaitu Pertama, tentang kesempurnaan suluk. Kedua, adab (etika). Ketiga, zikir. Keempat, muraqabah.

Adapun penjelasan secara detail tentang ajaran-ajaran toriqoh Qodiriah Naqsabandiah, Ahmad Khatib Al-Sambasi sebagai berikut; Pertama, kesempurnaan suluk (perjalan rohani seorang sufi) artinya adalah kesempurnaan suluk terdapat tiga dimensi yaitu Iman, Islam, dan Ihsan. Adapun ketiga dimensi tersebut populer dengan sebutan syari'at, tariqat, dan haqiqat. Syari'at adalah undang-undang dalam Islam. Tariqat, merupakan

${ }^{24}$ Nur Hidayat, Akhlak Tasawuf, (Yogyakarta: Ombak 2013), h. 37. 
pengamalan dari syariat yang didasarkan pada keimanan akan kebenaran syari'at. Haqiqat, penghayatan terhadap amalan tariqat.

Kedua, adab (etika) para murid. Adab bagian terpenting dalam perjalanan spritual seorang sufi untuk mencapai ma'riat. Tanpa etika yang baik tidak mungkin menggapai tingkat suluk-nya. Secara garis besar suluk yang dipraktikkan seorang salik mempunyai empat adab yaitu adab kepada Allah dan Rasul-Nya. Adab kepada syeikh atau mursid/gurunya, adab kepada sesama makhluk Allah SWT terutama saudara sesama muslim dan seiman, dan adab kepada diri sendiri.

Ketiga, ajaran tentang zikir dalam ajara toriqoh Qodiriah Naqsabandiah mempunyai ciri khas yang sendiri, berbeda dengan aliran toriqah yang lain. Zikir dalam tasawuf aliran toriqoh Qodiriah, Ahmad Khatib Al-Sambasi adalah zikir bermakna aktivitas lidah, baik lidah fisik maupun lidah batin dalam menyebut dan mengingat Allah SWT baik berupa jumlah (kalimat) maupun mufrod (kata tunggal). Dalam toriqoh Qodiriah Naqsabandiah terdapat dua jenis zikir yaitu zikir nafy itsbat dan zikir ism al-dzat. Zikir nafy itsbat merupakan zikir kepada Allah SWT dengan menyebut kalimat "La ilaha illa Allah", Sedangkan zikir ism dzat yaitu zikir menyebut dan mengucapkan lafal "Allah, Allah, Allah."

Keempat, muraqabah ialah kotemplasi kesadaran seorang hamba merasa selalu diawasi dan diperhatikan Allah SWT. Muraqabah merupakan latihan yang bersifat latihan psikis (riyadat al-nafs). Tujuan dari muraqabah adalah menjadi mukmin yang sesungguhnya. Seorang hamba Allah yang muhsin. ${ }^{25}$ Keempat pilar tersebutlah yang menjadi inti ajaran tasawuf tariqat Qodiriah Naqsabandiah, Ahmad Khatib Al-Sambasi.

${ }^{25}$ Solihin, Melacak Pemikiran Tasawuf di Nusantara..., h. 322-325. 


\section{Titik Temu Ajaran KH. Hasyim Asy'ari dan Syaikh Ahmad Khatib Sambas}

Pemikiran pendidikan Islam KH. Hasyim Asy'ari jika dianalisis dan disandingkan dengan pemikiran tasawuf aliran toriqoh Qodiriah Naqsabandiah, Ahmad Khatib Al-Sambasi memiliki titik temu dan kesamaan. Konsep pendidikan Islam yang digagas oleh khadratussyaikh KH. Hasyim Asy'ari tertuang di dalam kitab adab alAlim wa Muta'alim fima Yahtaj Ilah al-muta'alim Maqamat Ta'limih. Kitab ini menjelaskan tentang masalah-masalah pendidikan yang menekankan pada etika dalam kegiatan belajar mengajar. Etika merupakan bagian yang terpenting yang perlu diperhatikan dalam Pendidikan. Pemikiran Mbah Hasyim secara detail dapat dibagi beberapa bagian; Pertama, etika Murid dalam belajar. Kedua, etika guru dalam mengajar. Ketiga, etika terhadap buku pelajaran.

Sementara itu, pemikiran pemikiran pendidikan Islam Syaikh Ahmad Khatib al-Sambasi tertuang dalam ajaran tasawufnya yang beraliran toriqoh Qodiriah Naqsabandiah. Ajaran pokok Ahmad Khatib Al-Sambasi terdapat empat pilar utama, yaitu; Pertama, tentang kesempurnaan suluk. Kedua, adab (etika). Ketiga, zikir. Keempat, muraqabah. Adapun titik temu atau kesamaan pemikiran pendidikan Islam KH. Hasyim Asy'ari dan Syaikh Ahmad Khatib AlSambasi terletak pada pentingya etika, kesucian hati, kerendahan hati, mendekatkan diri kepada Allah SWT, dan etika lebih ditekankan dalam proses kegiatan belajar mengajar maupun pentingya etika seorang sufi dalam menggapai suluk-nya. Hal ini mejelaskan bahwa pemikiran pendidikan Islam KH. Hasyim Asy'ari mempunyai unsurunsur tasawuf sebagaimana termaktub dalam pemikiran Syaikh Ahmad Khatib Al-Sambasi.

Berdasarkan hal tersebut, maka dapat ditarik sebuah benang merah bahwa sesungguhnya pemikiran pendidikan Islam KH. Hasyim Asy'ari memang benar-benar membentuk karakter anak didik yang berkepribadiaan tasawuf. Pemikiran Pendidikan Islam KH. Hasyim Asy'ari ini sangat relevan jika diterapkan dalam konteks pendidikan 
saat ini yang kurang memperhatikan etika dalam proses kegiatan belajar mengajar.

Menurut hamat penulis, salah satu indikator "rusaknya" pendidikan Islam saat ini karena kurangnya mengedepankan nilainilai ke Islam-an dan kurang menekankan etika dalam kegiatan belajar mengajar baik di dalam maupun di luar kelas, sehingga mengakibatkan krisisnya spritualitas dalam dunia pendidikan. Etika menentukan arah berikir dan sikap anak didik, dengan etika yang baik sebagaiman telah dijelaskan dalam pemikiran KH. Hasyim Asy'ari dan Syaikh Ahmad Khatib Al-Sambasi maka akan membentuk pribadi anak didik yang berkepribadian akhlakul karimah (rendah hati, suci pemikiran dan suci hati serta dekat kepada Allah SWT).

Selanjutnya, "rusaknya" pendidikan baik berbasis Islam maupun umum ini dicerminkan dengan sikap anak didik yang mulai berani membantah, melawan, memukul bahkan bersikap kriminal kepada seorang pendidik/guru. Tidak sedikit kasus pemukulan dan tindakkekeraasan yang telah terjadi dan dilakukan oleh anak didik terhada guru. Misalnya dalam kasus "Penganiayaan Murid kepada Guru hingga mengakibatkan guru meninggal" karena kelalaian orang tua wali murid dalam mendidik anaknya. ${ }^{26}$

Peristiwa semacam ini bisa terjadi dikarenakan bukan hanya semata-mata kesalahan orang tua wali murid melainkan pendidikan saat ini benar-benar "krisis" spritual dan akhlak. Hal ini terjadi karena pendidikan tidak memperhatikan pentingnya etika dalam kegiatan belajar mengajar sebagaimana yang telah dijelaskan dalam kitab adab al-Alim wa Muta'alim fima Yahtaj Ilah al-muta'alim Maqamat Ta'limih karya KH. Hasyim Asy'ari dan krisisnya spritual dalam pendidikan karena kurangnya kegiatan keagamaan dalam pendidikan seperti istighosah bersama, membaca al-Quran 10 menit sebelum dimulainya kegiatan belajar mengajar serta kurangnya agenda sholat berjamaah dan zikir bersama antara murid dan guru setelah sholat. Hal ini

26 Eko Sutriyanto dalam http://www.tribunnews.com/regional/2018/02/ 03/penganiayaan-murid-ke-guru-bisa-jadi-akibat-salah-pola-asuh-yang-dilakukanorangtua. diakses pada hari Senin, 26 Maret 2018. Pukul 15.00 WIB 
mengakibatkan keringya kesucian hati, kesucian fikiran dan etika/akhlak dalam diri peserta didik dan pendidik.

\section{E. Kesimpulan}

Berdasarkan pada uraian yang telah dipaparkan sebelumnya, maka dapat penulis simpulkan jika konsep pemikiran pendidikan KH. Hasyim Asy'ari dan Syaikh Ahmad Khatib Al-Sambasi memiliki titik temu yang sama. Kedua tokoh tersebut, meski hidup berbeda zaman sama-sama mengedepankan kaidah atau etika serta etitude seorang santri atau murid bahkan gurunya dalam dalam belajar mengajar. Konsep pendidikan Islam Hasyim Asy'ari merupakan salah satu tawaran dalam mengatasi krisis spritual di dunia pendidikan saat ini. Pemikiran pendidikan Hasyim Asy'ari memang mempunyai nilai-nilai spritualitas tasawuf yang tinggi. Hal ini disebabkan, Hasyim Asy'ari meletakkan tasawuf sebagai pondasi pendidikan dalam membentukkan karakter peserta didik yang berakhlatul karimah dan memiliki intlektual yang mumpuni.

Konsep pendidikan Islam Hayim Asy'ari, jika dikaitkan dengan Konsep tasawuf Ahmad Khatib Al-Sambasi bukan hanya sekedar saling melengkapi satu sama lain, melainkan memperkuat teori pendidikan Islam Hasyim Asy'ari. Konsep pendidikan yang ditawarkan oleh KH. Hasyim Asy'ari dalam kitabnya memiliki relevansi dengan upaya dalam membentuk karakter peserta didik yang berakhlakul karimah, intlektual dan spritualitas. Melihat pendidikan di era modern saat ini yang lebih cenderung menekankan pada aspek kognitif meskipun dalam teori pendidikan terdapat unsur aspek kognitif, afektif dan psikomotorik. Keseriusan pendidikan dewasa ini yang menitikberatkan pada ranah kognitif berakibat pada kurang "keberkahannya" ilmu dari para peserta didik. Sehingga, salah satu bagian terpenting yang harus diperhatikan dan ditekankan selain pada aspek kognitif adalah aspek afektif (spritualitas dan etika) dalam proses belajar mengajar, baik sebagai guru atau murid dalam pendidikan. Sudah saatnya pendidikan lebih mengutamakan aspek afektif (moral, etika dan spritual). Krisis spiritual, etika dan moral 
menjadi kajian penting dalam dunia pendidikan terlebih pendidikan berbasis Islam.[]

\section{Daftar Pustaka}

Dahlan Tamrin, Tasawuf Irfani, Malang: UIN Maliki Press, 2010

Eko Sutriyanto dalam http://www.tribunnews.com/ regional/ 2018/ 02/03/penganiayaan-murid-ke-guru-bisa-jadi-akibat-salahpola-asuh-yang-dilakukan-orangtua. diakses pada hari Senin, 26 Maret 2018. Pukul 15.00 WIB

https://id.wikipedia.org/wiki/Achmad_Khotib_al-Syambasi, pada tanggal 19 Februari 2018. Pukul 09.00 WIB.

Nur Hidayat, Akhlak Tasawuf, Yogyakarta: Ombak 2013

Ramayulis dan Samsul Nizar, Ensiklopedi Tokoh Pendidikan Islam, Ciputat: PT. Ciputat Press Group, 2005.

Rosihon Anwar, Akhlak Tasawuf, Bandung: CV Pustaka Setia, 2010

Samsul Nizar, Filsafat Pendidikan Islam Pendekatan Historis Teoritis dan Praktis, Jakarta Selatan: Ciputat Pers, 2002

Solihin, Melacak Pemikiran Tasawuf di Nusantara, Jakarta: PT. Raja Grafindo, 2005

Yunasril Ali, Pilar-Pilar Tasawuf, Jakarta: Kalam Mulia, 2005

Zainal Abidin, Filsafat Pendidikan Islam, Metro: STAIN Jurai Siwo Metro Lampung, 2013 